\title{
Fostering Metacognitive Reading Strategies in Thai EFL Classrooms: A Focus on Proficiency
}

\author{
Charinwit Seedanont ${ }^{1} \&$ Suphawat Pookcharoen ${ }^{2}$ \\ ${ }^{1}$ Department of Foreign Languages, Saint Gabriel's College, Bangkok, Thailand \\ ${ }^{2}$ Department of English and Linguistics, Thammasat University, Bangkok, Thailand \\ Correspondence: Charinwit Seedanont, Saint Gabriel's College, 565 Samsen Rd., Vajiraphayaban, Dusit, \\ Bangkok, Thailand.
}

\author{
Received: May 11, 2019 Accepted: June 13, 2019 Online Published: June 15, 2019 \\ doi: 10.5539/elt.v12n7p75 URL: https://doi.org/10.5539/elt.v12n7p75
}

\begin{abstract}
EFL readers tend to experience a number of challenges while learning, due to a number of factors that affect how these readers achieve their learning goals. Metacognitive strategies, referring to one's deliberate, goal-directed control over cognitive enterprises, are considered crucial for assisting EFL learners to be able to accomplish comprehension while reading. Previous studies have enriched the knowledge of metacognitive reading strategies in EFL settings. However, only few investigations yielded statistically significant effects on learners' reading performance. This present study hence foresees an opportunity to shed new light on this issue by focusing on EFL learners' proficiency. The objectives of this research are twofold: exploring the effects of the metacognitive strategy instruction on the strategy awareness, and perceiving the effects of the instruction on the reading performance in taking a standardized test. Forty-three students enrolling in a private male school in Bangkok, Thailand participated in the study, lasting ten weeks. A wide range of research tools were administered: SORS, IELTS reading test, and lesson plans. The findings suggested that the students' awareness of reading strategies used in terms of sub-categories and IELTS reading test score improved with statistical significance. Pedagogical implications and suggestions for future research studies are discussed based on the findings.
\end{abstract}

Keywords: EFL reading, metacognitive strategy instruction, reading ability

\section{Introduction}

\subsection{Statement of the Problem}

Learning to read in contexts of English as a foreign language (EFL) is considered challenging among learners (Koda, 2005). A number of factors, including metacognitive knowledge or the acquired knowledge or beliefs of a person on cognitive enterprises, affect the approach to which each student subscribes, in order to achieve learning goals (Ismail \& Tawalbeh, 2014; Liu, 2014). Referring to one's deliberate, goal-directed control over cognitive enterprises (Pinninti, 2016), metacognitive strategies are considered crucial for assisting EFL learners to be able to accomplish comprehension while reading (O'Malley \& Chamot, 1990). Translating from English to the native language, adjusting the reading speed, and setting purposes prior to reading are the strategy samples that constitute the repertoire of reading strategies which readers can later exercise to facilitate their reading. Previous research studies have enriched the knowledge of metacognitive reading strategies in EFL settings. Only few investigations yielded significant effects on learners' reading ability, due to a variety of issues regarding research methodology: instructional models applied, in particular. This present study hence introduces a new methodology in order to shed new light on the effects of the metacognitive strategy instruction on the reading ability of EFL students.

\subsection{Purposes of the Study}

The purposes of the present research study are twofold. First and foremost, it aims at exploring the effects of the metacognitive strategy instruction in EFL reading class offered on Thai EFL students' awareness toward reading strategies. The lessons on metacognitive reading strategies lead to another goal of the study, which is to perceive the effect of the instruction on the participants' reading performance in taking a standardized test. 


\subsection{Significance of the Study}

The findings of the study could be applied in a variety of dimensions concerning EFL reader lessons. Regarding the level of the students' reading strategy awareness, EFL teachers and educators could use the results for designing appropriate teaching plans in order to foster EFL students' reading comprehension, and by extension, their reading performance.

Besides pedagogical implications, the students themselves are also able to strategically address problems that may arise while reading English texts, for they acknowledge the effectiveness of the metacognitive reading strategies.

The exploration of the study is expected to enlighten researchers in the field of EFL and English language teaching (ELT) to investigate more on the effects of the metacognitive strategies, so as to delimit the learning arising within the world where incessant information flows across every aspect of living (Koda, 2005).

\section{Literature Review}

\subsection{Background in Thai EFL Reading}

Reading in a foreign language (FL) is considerably challenging, for it involves two or more languages. In addition, past studies related to FL reading disclose that the challenge derives from a number of factors, namely, prior knowledge, first language (L1) and second language (L2) proficiency, and metacognitive knowledge. FL reading hence requires more time for learners to successfully improve in reading (Phaiphimai \& Meesri, 2015).

In the realm of EFL, reading is regarded as one of the key skills in learning. However, the attempts to apply the efficient skills for the English language in national curricula among non-Anglophone countries seem vulnerable, due to a wide range of sociocultural issues (Zhao \& Zhu, 2012; Shaaban, 2014; DeWaelsche, 2015; Djamàa, 2016), not to mention the important influence of teachers in English classrooms and learning assessment (Fahim \& Sa'eepour, 2011; DeWaelsche, 2015; Zhou et al., 2015; Djamàa, 2016).

In Thailand, English language has also been instructed as a foreign language. However, despite years of studying EFL, Thai students' reading ability is evidently limited (Jaengsaengthong, 2016). To address such a concern, the Ministry of Education in Thailand has attempted to revise the country's national curriculum regarding the English language so as to enhance the language proficiency. A paradigm shift on English language instruction has been witnessed in the educational circles. A number of changes have been made to underline the virtue of English language importance either for further studies in tertiary level or for professional communications in the future (Pookcharoen, 2009). Still, the improvements have not been significant (Phaiphimai \& Meesri, 2015). To address the problem among Thai EFL learners, a number of researchers in past studies suggested reading strategy instruction (e.g., Sudachit, 2005; Chomphuchart, 2007; Phaiphimai \& Meesri, 2015). It is believed that reading strategies are able to assist EFL learners to enhance their reading comprehension (Chomphuchart, 2007). In addition, teaching such strategies allows learners to have positive beliefs towards themselves. This hence affects how learners perceive and manage their anxiety when approaching unfamiliar texts. Therefore, better learning results are promising (Lien, 2016).

\subsection{Metacognition in EFL Reading Comprehension}

Metacognition, according to Brown (1980) is referred to as "the deliberate conscious control of one's own cognitive actions" (p. 453). Meanwhile, Jacobs and Paris (1987) define the term as "reportable, conscious awareness about the cognitive aspects of thinking" (p. 258).

The discussion regarding metacognition often leads to the study by John Flavell (1979), who coined the term. The metacognition pioneer accentuates that two key components occur simultaneously: metacognitive knowledge, and metacognitive experiences. While the former refers to the acquired knowledge or beliefs of a person on cognitive enterprises, the latter refers to the application of metacognitive strategies or metacognitive regulation.

Metacognition in reading is referred to as "the ability to reflect on one's reading to understand, regulate and self-guide the process of reading" (Pinninti, 2016, p. 181). Hence, metacognitive reading strategies are those strategies employed to plan for, regulate, and evaluate reading enterprises. According to Mokhtari and Sheorey (2002), metacognitive reading strategies can be divided into three subcategories: global, problem-solving, and support strategies. The knowledge of these strategies recalls the concept of metacognitive knowledge, which is considered the key factor that can successfully improve reading, especially those in foreign language environments.

When the awareness of the acquired strategies and the knowledge of how and when to exercise one of the 
strategies appropriate for each learning tasks are present, the desirable outcomes can be perceptible. This is due to the control of metacognitive strategies over any other strategies (O’Malley \& Chamot, 1990).

In the realm of reading, metacognitive reading awareness can facilitate reading comprehension, contributing to EFL/ESL learning (Mokhtari \& Reichard, 2002; Albazi \& Shukri, 2016). Concerning the effectiveness of the application of metacognitive reading strategies in EFL/ESL communities, effective application is confirmed in the article of Albazi and Shukri (2016).

\subsection{Metacognitive Reading Strategy-related Research in EFL Contexts}

A study by Sheorey and Mokhtari (2001) aimed at suggesting a survey of reading strategies. Based on and developed from the Metacognitive Awareness of Reading Strategy Inventory (MARSI) which is intended to perceived the metacognitive awareness of reading strategies among native-English speakers, the Survey Of Reading Strategies (SORS) comprises three categories of reading strategies: global, problem-solving, and support strategy clusters. The researchers attempted to perceive the differences between ESL and college students in the United States and native-English speaking American students, and also between genders. The study revealed that ESL students reported a wider range of strategies used while reading than their American counterparts. Meanwhile, no statistical significance was perceived between male and female participants.

Regarding the applications of both MARSI and SORS, a wide spectrum of studies across the corpora revealed different outcomes.

In the research of Yüksel and Yüksel (2012), the metacognitive awareness of academic reading strategies among Turkish universities is studied. The participants were 16 Turkish EFL students enrolling at the Faculty of Education, Anadolu University. These students took EFL reading as compulsory courses. They were trained on effective reading strategies during their university education. The researchers collected the data regarding the participants' metacognitive awareness by using SORS. The finding reveals that these students usually employed reading strategies. According to the researchers, this is the sign that the respondents were aware of academic reading strategies. Regarding the sub-categories of metacognitive reading strategies, the use of problem-solving strategies was predominant. Meanwhile, these participants employ supporting strategies the least in their academic reading.

It is interesting to note that merely the levels of metacognitive reading strategy use were measured. Another noteworthy issue in investigating the application of metacognitive reading strategies is to associate the findings with the participants' reading abilities. Such an association allows instructors and educators to profit from the pedagogical implications, to better plan the learning activities that are able to maximize the reading abilities of students, both proficient and less proficient (Pookcharoen, 2009; Phaiphimai \& Meesri, 2015).

Regarding the metacognitive reading awareness in Indian contexts, Pinninti (2016) conducted a study on nine ninth-graders. The participants were asked to write reflective journals. In addition, prompts-such as "I used these strategies to deal with the difficult parts of the text", "I used these strategies effectively", and "these strategies did not work for me" (p. 183)-are provided prior to the journal writing. The researcher based the prompts of this study from those available in a research on the development of listening strategies. The researcher then analyzed these journals qualitatively, using thematic analysis, focusing on state-wise frequency (pre-, while-, and post-reading). The research finding uncovers that the most frequently used strategies in pre-reading stage were previewing and predicting. Regarding strategies in while-reading stage, underlining unfamiliar words and rereading difficult sentences were reported each with the highest frequency of usage. In terms of post-reading strategy category, discussing with friends and recalling summary were highly employed among the participants. Meanwhile, pre-reading strategies that were reported being the least were recalling the past and thinking of purpose. In the category of while-reading strategies, asking teacher and discussing with friends were found to be exercised the least. In addition, the post-reading strategies reported with the fewest exercises were visualizing and renaming the title.

The validity of the research is questionable. While the researcher tended to investigate the frequently and least frequently used reading strategies, the prompts suggested to the participants were taken from a listening strategy study. Hence, the research instrument-or in this research, the prompts-lacked the construct validity, discussing whether a research instrument measures what it is designed to do (Ellis et al., 2009).

Meanwhile, the studies related to metacognitive reading strategy instruction in a variety of contexts yielded different findings.

Regarding metacognitive pedagogical model, a quasi-experimental study on second year students at the Eurasian National University by Zhussupova and Kazbekova (2016). There were 60 students participating in the 15 -week 
experiment; they were then studying Basic English, for which the researchers were responsible. The participants are divided into 2 groups: control group (CG) and experimental group (EG). First Certificate English Reading Test was first and foremost administered to confirm no significant difference between these two groups. The CG was taught English as they are traditionally treated, whereas the EG was offered an intervention developed under the metacognitive pedagogical model. For the proper process of teaching under metacognitive pedagogical model, a teacher's manual in teaching reading strategies was suggested. During the intervention, the researchers observed the participants in both groups. Also, these students take a test after the intervention process. The finding suggests that the EG improved more in terms of reading abilities, than those in the CG.

The improvement, however, is doubtful, for such a progress is only yielded from the reading comprehension test. The awareness levels of metacognitive reading strategies were not measured. The research, hence, does not represent the effects of metacognitive reading strategy intervention. Rather, it unveils the effects of a teaching model on students' reading abilities. The effects of the teaching model can more or less decay, according to Gandhimathi and Ganesan (2010).

Meanwhile in Thai context, the effects of metacognitive strategy instruction on EFL Thai students reading comprehension ability were investigated by Wichadee (2011). The participants were 40 EFL students at a private university in Thailand. A reading comprehension test and a metacognitive reading strategy awareness survey, both created by the researcher, were administered prior to the intervention in order to identify the levels of English proficiencies, reading abilities, respectively. The intervention consisted of thirteen 45-minute sessions. Both the reading comprehension test and the metacognitive strategy awareness survey were provided to measure the effects. In addition, semi-structured interview was also held to gain the participants' perception toward the strategy instruction. Based on the comprehension post-instruction test score, five students with highest marks along with five participants awarded the least points were to take part in the semi-structured interview. The findings of the research suggested that proficient, moderate, and less proficient students improved in terms of reading abilities and reading strategy awareness. However, regarding the interview, the proficient representatives perceived that strategy instruction was effective in promoting their reading abilities. However, the less proficient students were not certain about the effectiveness of the strategy instruction, for some strategies were rather difficult and abstract to put into action.

\subsection{Language Learning Strategy Instructional Models}

The models of learning strategy instruction have been the research centrality among educators across the globe (Liu, 2010). The key models widely recognized are Oxford's (1990) Model, and Grenfall and Harris's (1999) Model.

Oxford's (1990) model fosters the independent use of learning strategies, but in different perspectives. Based on the model, an authentic language task is provided to the students without guidelines. Next, the teacher suggests and describes some helpful strategies, in order to promote self-direction and the practical benefits of the strategies. At this stage, the learners can understand the ground of the strategy application. After such a discussion, new tasks are provided to these students. Also, a plenty of time is allowed for the practice. The teacher demonstrates at this point how the strategies can be applied in new learning tasks. Later, an exercise is offered to enable learners to practice using the strategies. Finally, the instructor guides these students on how to evaluate the success of their strategy applications, along with the progress on responsibility and self-direction. Modifications and rearrangements of steps can be made when instructors apply this model in teaching learning strategies.

Another model of language learning strategy instruction was developed by Grenfall and Harris (1999). The model consists of 6 different steps as follows. Students' awareness of strategy use is primarily underlined by asking students to identify the strategies they use in the practice they do on their own. Then, the discussion regarding new strategies is exercised through the instructor's modeling. Also at this stage, a checklist of strategies is provided so that the students can later employ while completing a language task. Next, different exercises are provided so as to allow the students to apply the new strategies. After the exercises are completed, prior to dealing with focused practices, the learners need to set their goals and select the learning strategies that can enable them to realize those aims. In the following step, the teacher fades his/her assistance so that these students are able to exercise the strategies automatically.

\section{Methodology}

\subsection{Research Questions}

To achieve the purposes of this present study, two research questions were formulated: 
1) To what extent does the metacognitive strategy instruction affect the participants' awareness of reading strategies?

2) What are the effects of the instruction on the students' reading performance?

\subsection{Participants and Context}

The participants were 43 male Thai EFL students enrolling in grade 11 in the academic year of 2018, at a private male school in Bangkok, Thailand. The participants were under science and mathematics program. Regarding EFL courses, the students enrolled in two EFL subjects each semester. One course was related to English Grammar, whereas another was designed to introduce the participants into the realm of EFL reading, appropriate for their study level.

\subsection{Research Instruments}

The period during which the instruction and data collection was conducted lasted 10 weeks (November 2018-mid-January 2019). A wide range of research instruments were exercised to collect data: the Survey of Reading Strategies (SORS), IELTS reading proficiency test scores, and instruction sessions, and semi-structured interviews.

Regarding the instruction sessions, lesson plans were designed based on two strategy instructional models: Oxford (1990) and Grenfall and Harris (1999). Following is the proposed, hybrid model for metacognitive reading strategy instruction.

To design the model, the total number of strategies and clusters had to be put into consideration. The reading strategies, according to Mokhtari and Sheorey (2002), are classified into three groups: global, problem-solving, and support strategies. In order to raise awareness among learners about reading strategies, the first sessions should be reserved for awareness raising activities. In those sessions, past reading strategy applications of students are shared, in order to establish learners' engagement. On this occasion, learners discuss their perceptions toward the reading strategies. The strategy application may be required to assist those with no experience of using certain learning devices, to help visualize the use. During the stage, a reading task is provided so that the classroom can have evidence to support the discussion. Also, a list of reading strategies discussed is created to facilitate later usages.

Once the first few sessions are designed for raising awareness toward reading strategy application, the target reading strategies are then focused in group: global, problem-solving, and support strategies. It is worth to note that the teacher can rearrange the order of the strategy group discussion, based on particular contexts that may arise.

Each strategy cluster discussion begins with the awareness raising, either guessing what strategies belong to the cluster, or the past experience of employing strategies deemed belonging to the group. When a discussion is on for some time, a learning task is assigned for students to do in groups or try completing the task individually. The group assignment allows students to cluster with peers who can more or less suggest and model the usage of the targeted strategies, and even associate the application combination. This can foster creativity in terms of strategy application, not to be restricted to one strategy per one task. An individual task can assist students to work autonomously. While no assistance from peers is available, learners are able to practice their usage creativity on their own. Then, the highlights of either the discussion or the reflection on personal experiences in working on a task alone will be brought to class. Advised is to frequently provide a reading strategy checklist, to enable students to keep track of their reading strategy learning. The key point in this section is to try to engage as much as possible students.

The last section of the model is the reading strategy seminar, where students are able to arrange a seminar on reading strategy by attempting at a variety of readings: lyrics, comic strips, poems, documentary abstracts, literary excerpts, etc. Students are allowed to be creative about the strategies used as much as possible. On the seminar sessions, visual aids are allowed to facilitate the listening. Discussions and comments can be vivid for the whole class to follow or share their ideas on their turns.

\subsection{Research Procedures}

Concerning the data collection procedures, there were three phases. The first phase required the participants do the IELTS reading test and complete SORS. The phase was complete during the first two class hours. The second phase of the study was the sessions. The instruction was conducted as each lesson plan suggested. There were 18 sessions. In the final phase, the students needed to take a new set of IELTS reading test, followed by SORS. 


\section{Findings and Discussions}

\subsection{Findings of the First Research Question}

Pre- and Post-instruction SORS Responses and Paired T-test Values

\begin{tabular}{|c|c|c|c|c|c|c|}
\hline \multirow{2}{*}{\multicolumn{2}{|c|}{ Strategy }} & \multicolumn{2}{|c|}{ Pre-instruction } & \multicolumn{2}{|c|}{ Post-instruction } & \multirow[t]{2}{*}{ Sig. (2-tailed) } \\
\hline & & Mean & S.D. & Mean & S.D. & \\
\hline \multicolumn{7}{|c|}{ Global Strategies } \\
\hline 1 & Having a purpose in mind & 4.05 & 1.00 & 4.40 & 0.73 & 0.02 \\
\hline 3 & Using prior knowledge & 4.05 & 1.09 & 4.23 & 0.78 & 0.27 \\
\hline 4 & Taking an overall view prior to reading & 3.42 & 1.10 & 4.09 & 0.84 & $<0.01$ \\
\hline 6 & Analyzing if text fits reading purpose & 3.93 & 1.12 & 4.00 & 0.95 & 0.70 \\
\hline 8 & Noting length and organization & 3.88 & 1.20 & 4.35 & 0.72 & 0.03 \\
\hline 12 & Deciding what to read closely & 3.21 & 1.19 & 3.95 & 1.00 & $<0.01$ \\
\hline 15 & Using tables, figures, and pictures & 3.63 & 1.23 & 3.88 & 1.05 & 0.27 \\
\hline 17 & Using context clues & 4.12 & 1.07 & 4.19 & 0.96 & 0.65 \\
\hline 20 & Using typographical features to assist reading & 4.14 & 0.94 & 4.30 & 0.96 & 0.32 \\
\hline 21 & Evaluating information read & 3.42 & 1.24 & 3.86 & 0.89 & 0.03 \\
\hline 23 & Checking my understanding & 3.42 & 1.03 & 3.84 & 0.84 & 0.03 \\
\hline 24 & Guessing what the content is about & 3.07 & 1.32 & 3.70 & 1.01 & $<0.01$ \\
\hline 27 & Confirming predictions & 2.98 & 1.28 & 3.44 & 0.98 & 0.02 \\
\hline & Total & 3.64 & 0.53 & 4.02 & 0.50 & $<0.01$ \\
\hline \multicolumn{7}{|c|}{ Problem-solving Strategies } \\
\hline 7 & Reading slowly and carefully & 3.63 & 1.13 & 4.19 & 0.88 & $<0.01$ \\
\hline 9 & Trying to stay focused on reading & 4.09 & 0.89 & 4.21 & 0.86 & 0.43 \\
\hline 11 & Adjusting reading speed & 3.79 & 1.17 & 4.07 & 0.83 & 0.15 \\
\hline 14 & Paying closer attention to reading when text is difficult & 3.72 & 1.08 & 4.19 & 0.93 & 0.02 \\
\hline 16 & Pausing and thinking about reading & 2.88 & 1.14 & 3.53 & 0.83 & $<0.01$ \\
\hline 19 & Visualizing information read & 3.65 & 1.25 & 4.28 & 0.85 & $<0.01$ \\
\hline 25 & Rereading for better understanding & 4.00 & 1.05 & 4.14 & 0.80 & 0.51 \\
\hline 28 & Guessing meaning of unknown words & 3.88 & 1.20 & 4.09 & 0.87 & 0.28 \\
\hline & Total & 3.71 & 0.51 & 4.09 & 0.47 & $<0.01$ \\
\hline \multicolumn{7}{|c|}{ Support Strategies } \\
\hline 2 & Taking notes while reading & 1.74 & 0.95 & 3.05 & 0.95 & $<0.01$ \\
\hline 5 & Reading aloud when text is difficult & 2.56 & 1.55 & 3.42 & 0.98 & $<0.01$ \\
\hline 10 & Marking information to assist remembering & 3.35 & 1.40 & 4.12 & 0.96 & $<0.01$ \\
\hline 13 & Consulting reference materials & 3.49 & 1.30 & 2.93 & 0.94 & $<0.01$ \\
\hline 18 & Paraphrasing for better understanding & 3.72 & 1.08 & 4.05 & 1.05 & 0.09 \\
\hline 22 & Going back and forth in text & 3.79 & 1.08 & 3.98 & 0.89 & 0.21 \\
\hline 26 & Asking myself questions & 2.81 & 0.96 & 3.58 & 1.01 & $<0.01$ \\
\hline 29 & Translating from English to Thai & 3.44 & 1.30 & 3.51 & 1.26 & 0.67 \\
\hline \multirow[t]{2}{*}{30} & Thinking in both English and Thai & 3.47 & 1.14 & 3.72 & 1.14 & 0.23 \\
\hline & Total & 3.15 & 0.51 & 3.59 & 0.58 & $<0.01$ \\
\hline
\end{tabular}


The table illustrates the mean score and the value of standard deviation for each strategy, and the paired t-test values of each strategy and all SORS sub-categories. Regarding the strategies reported in the pre-instruction SORS with the highest frequency of usage, using typographical features to assist reading was reported with the average value of 4.14 , and the standard deviation value of 0.94 . The strategies listed in the problem-solving strategy and support strategy clusters, which yielded the highest usage frequency of each group, were trying to stay focused on reading $(M=4.09 ; S D=0.89)$ and going back and forth in text $(M=3.79 ; S D=1.08)$, respectively.

Meanwhile, the post-instruction responses yielded different results in terms of the highest mean score. Of all reading strategies listed in the survey, having a purpose in mind, one of the global strategies, obtained the highest average value $(M=4.40 ; S D=0.73)$. Visualizing information read was reported with the highest usage frequency among the problem-solving strategies $(M=4.28 ; S D=0.85)$. In the classification of support strategies, marking information to assist remembering was reported with the average value of 4.12 , and the standard deviation value of 0.96 . The strategies with the highest frequencies as reported in both SORS administrations lead to the investigation in the level of strategy subcategories.

The pre-instruction average score of global strategy group was 3.64 with 0.53 as the standard deviation value, whereas the post-instruction mean value was 4.02 with 0.50 as the standard deviation. The difference yielded from both SORS administrations contribute to the statistical significance; $p<0.01$. The findings suggested that the metacognitive strategy instruction had potential effects on the perceived use of global strategies. However, the paired t-test values of all strategies in the group were not reported unanimous. That is, there existed eight strategies able to reach statistical significance level: nos. 1, 4, 8, 12, 21, 23, 24, and 27. Unlike these strategies, the other five were not classified in the statistical significance: nos. 3, 6, 15, 17, and 20. To explain the phenomenon, the mean values of these strategies' pre- and post-responses were considered. Oxford and Burry-Stock (1995) stress that the means can be classified into three groups: high usage group with the average value of 3.50 or above, medium usage group holding the mean score between 2.50 and 3.49 , and low usage group with the mean value below 2.50. The average values of the five strategies were reported above 3.50, both in pre- and- post intervention SORS. This hence explained that the research participants used the strategies frequently.

In terms of problem-solving strategy cluster, the statistical significance was also reported; $p<0.01$. This was derived from the improvement of the mean score of the subcategory when compared between both SORS administrations. That is, the first SORS administration revealed that the average value of problem-solving subcategory was 3.71 with the standard deviation value of 0.51 . Meanwhile, the value of average yielded from the post-instruction SORS was 3.59 with the standard deviation of 0.58 . The research findings disclosed that the instruction had firm potentials on the strategy use among the participants. In details, four out of eight strategies enlisted in the sub-category were reported with statistical significance: nos. 7, 14, 16, and 19. There existed also four strategies not considered statistically significant: nos. 9, 11, 25, and 28. According to Oxford and Burry-Stock (1995), the average responses of the latter strategy group reached the high usage level both before and after the metacognitive reading strategy instruction. The phenomenon of strategies under this sub-category was similar to that of the global strategy group.

Regarding the strategies classified as support strategies, the statistical significance was reported; $p<0.01$. This was supported by the average scores retrieved from pre- and post- instruction SORS administrations. That is, the average and standard deviation values of the subcategory in pre-intervention survey were 3.15 and 0.51 , respectively. Meanwhile, the average and standard deviation values of the post-instruction SORS were 3.59 and 0.58 , respectively. This confirmed that the instruction potentially affected the perception of strategy application among the research participants. Five strategies, however, were reported with statistical significance: nos. 2, 5, 10,13 , and 26. The strategies not considered statistically significant were nos. 18, 22, 29, and 30 . It is noteworthy that the phenomenon of this sub-category was not similar to that of the former groups. That is, there existed two strategies whose average scores reached the high usage level in both phases of SORS administrations. Those strategies were nos. 18, and 22. Meanwhile, a slight rise was perceived from the strategies marked nos. 29 , and 30. Based on SORS administered before the intervention, the mean values of these strategies $(\mathrm{M}=3.44$ and 3.47 , respectively) were classified in the medium usage level (Oxford \& Burry-Stock, 1995). The average values of these two strategies increased to 4.14 and 4.09 , respectively. These values were labeled among high usage strategies.

It is captivating to approach the average scores of the post-instruction SORS in the sub-category perspective. The three sub-category mean values improved with statistical significance. This stresses the effectiveness of the metacognitive strategy instruction on the perceived use of these strategies. However, this outcome is not 
consistent with the findings in Chinese EFL context by Pei (2014), which disclosed that there was no statistical significance after the strategy instruction with regards to the metacognitive strategy awareness. The differences in terms of methodology between this present study and that of Pei (2014) lie in the matter of instruction period and the instructional model. That is, this present experiment was designed to be a semester-long instruction, consisting of 20 sessions that lasted 50 minutes each. The instructional model applied in this study was integrated from the model of Oxford (1990) and that of Grenfall and Harris (1999). Meanwhile, the investigations in Chinese EFL contexts by Pei (2014) were conducted within 8 weeks. Each session of the metacognitive strategy instruction lasted 15 minutes. In addition, the different instructional model was exercised in the research study: Cognitive Academic Language Learning Approach (O'Malley \& Chamot, 1994). The two different issues extracted were the key contributors for the statistical significance level.

In this study, the results of both SORS administrations yielded similar use order of the reading strategies according to the three sub-categories. That is, problem-solving strategies were reported with the highest frequency use, followed by global strategy group, and support strategies cluster, respectively. The findings are in line with those of previous studies (Pressley \& Afflerbach, 1995; Sheorey \& Mokhtari, 2001; Yüksel \& Yüksel, 2012). Also in EFL online reading context, such outcomes are identical to the results of the research by Pookcharoen (2009). Regarding the problem-solving strategy cluster in particular, the previous investigations conducted by Pammu et al. (2014) and Jaengsaengthong (2016) echo similar findings in terms of the strategy group with the highest frequency usage. Pookcharoen (2009) supported this phenomenon by arguing that the problem-solving strategies are exercised the most when Thai EFL students perform reading English passages as if this was the problem-solving actions in general.

It can hence be concluded that the metacognitive strategy instruction could improve the awareness of the participants in terms of reading strategy sub-categories. All three strategy clusters yielded the improvement with statistical significance at 0.01 . Noteworthy are almost two-third of individual strategies reached statistical significance level. This hence underlines the effectiveness of the metacognitive strategy instruction on the awareness of the participants. This new light can more or less lead researchers in the field of ELT and EFL to extend the research findings into other contexts.

\subsection{Findings of the Second Research Question}

Results of Pre- and Post-instruction IELTS Reading Band Scores

\begin{tabular}{|c|c|c|c|c|c|}
\hline \multirow[b]{2}{*}{ Pseudonym } & Pre-instruction & Post-instruction & \multirow[b]{2}{*}{ Pseudonym } & Pre-instruction & Post-instruction \\
\hline & $\begin{array}{l}\text { IELTS Reading } \\
\text { Band Score }\end{array}$ & $\begin{array}{l}\text { IELTS Reading } \\
\text { Band Score }\end{array}$ & & $\begin{array}{l}\text { IELTS Reading } \\
\text { Band Score }\end{array}$ & $\begin{array}{l}\text { IELTS Reading } \\
\text { Band Score }\end{array}$ \\
\hline Student 01 & 6 & 9 & Student 24 & 6.5 & 6.5 \\
\hline Student 02 & 8.5 & 8.5 & Student 25 & 5 & 6 \\
\hline Student 03 & 6 & 8.5 & Student 26 & 4 & 6 \\
\hline Student 04 & 7 & 8.5 & Student 27 & 5.5 & 6 \\
\hline Student 05 & 7.5 & 8.5 & Student 28 & 4.5 & 6 \\
\hline Student 06 & 7.5 & 8.5 & Student 29 & 4 & 6 \\
\hline Student 07 & 8 & 8.5 & Student 30 & 4 & 6 \\
\hline Student 08 & 8.5 & 8.5 & Student 31 & 4 & 5.5 \\
\hline Student 09 & 5.5 & 8 & Student 32 & 4.5 & 5.5 \\
\hline Student 10 & 8 & 8 & Student 33 & 4.5 & 5.5 \\
\hline Student 11 & 5.5 & 8 & Student 34 & 5.5 & 5.5 \\
\hline Student 12 & 6.5 & 7.5 & Student 35 & 5 & 5.5 \\
\hline Student 13 & 6.5 & 7.5 & Student 36 & 4 & 5.5 \\
\hline Student 14 & 6.5 & 7.5 & Student 37 & 4.5 & 5 \\
\hline Student 15 & 6 & 7.5 & Student 38 & 4 & 5 \\
\hline Student 16 & 6.5 & 7.5 & Student 39 & 4 & 4.5 \\
\hline
\end{tabular}




\begin{tabular}{|c|c|c|c|c|c|}
\hline \multirow{3}{*}{ Pseudonym } & Pre-instruction & \multicolumn{2}{|l|}{ Post-instruction } & Pre-instruction & Post-instruction \\
\hline & IELTS Reading & IELTS Reading & Pseudonym & IELTS Reading & IELTS Reading \\
\hline & Band Score & & & & \\
\hline Student 17 & 7 & 7 & Student 40 & 5 & 4.5 \\
\hline Student 18 & 4.5 & 7 & Student 41 & 4 & 4.5 \\
\hline Student 19 & 6.5 & 7 & Student 42 & 4 & 4.5 \\
\hline Student 20 & 5 & 7 & Student 43 & 4 & 4.5 \\
\hline Student 21 & 5 & 7 & Average & 5.54 & 6.65 \\
\hline Student 22 & 5 & 6.5 & SD & 1.38 & 1.37 \\
\hline Student 23 & 4.5 & 6.5 & & & \\
\hline
\end{tabular}

The table above illustrates the IELTS reading test results of the 43 students. Regarding the pre-instruction test band scores, the average value was 5.54 and the standard deviation value was 1.38 . The highest band score awarded was 8.5, and the lowest band score was 4 . There existed 17 students that could obtain the reading band score over the average value. The post-instruction test results revealed that the mean score was 6.65 and the standard deviation was 1.37. The highest band score was 9, and the lowest band score was 4.5. Twenty-one entries were reported above the average score. It can be perceived that the different band score average value of both test administrations was 1.11. The rather tremendous gap invites further statistical analysis. The table below hence presents the paired t-test score of the IELTS reading test administrations.

Paired T-test Value of the IELTS Reading Test Administrations

\begin{tabular}{|c|c|c|c|c|c|c|c|}
\hline \multirow{3}{*}{ IELTS Reading Test } & \multicolumn{4}{|c|}{ Paired Differences } & \multirow[t]{3}{*}{$\mathbf{t}$} & \multirow[t]{3}{*}{ df } & \multirow{3}{*}{ 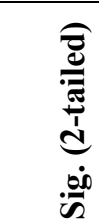 } \\
\hline & \multirow[t]{2}{*}{ Mean } & \multirow{2}{*}{$\begin{array}{l}\text { Std. Error } \\
\text { of } \\
\text { difference }\end{array}$} & \multicolumn{2}{|c|}{$\begin{array}{l}95 \% \\
\text { of Confidence }\end{array}$} & & & \\
\hline & & & Lower & Upper & & & \\
\hline $\begin{array}{l}\text { Pre-instruction and post-instruction } \\
\text { administrations }\end{array}$. & -1.11 & 0.13 & -1.38 & -0.85 & 8.60 & 42 & $<0.01$ \\
\hline
\end{tabular}

The table demonstrates the paired t-test value of both pre- and post-instruction IELTS reading test administrations: $t(42)=9.48 ; p<0.01$. It can hence be concluded that the quantitative effects of the metacognitive reading strategy instruction on the research participants' reading ability were positively perceptible with statistical significance.

It can hence be stated that the participants of this present study contributed to the increase in the average score. The findings of this study correspond with those explored by Tanjitanont (2016), and Zhussupova and Kazbekova (2016). It is interesting to note that in this research study, the increase in standardized reading test band score was reported with statistical significance. This accentuates the effectiveness of the strategy on the research participants. In addition, such results support previous suggestions that explicit strategy instruction should be executed to raise both the awareness of metacognitive reading strategies and the performance in taking English reading test (Wichadee, 2011; Ismail \& Tawalbeh, 2014; Iwai, 2016; Meniado, 2016). According to the investigation of Pei (2014) revealing the effects of the metacognitive strategy with no statistical significance level, the researcher suggested that the phenomenon might derive from the insufficient time of each instruction session. It was argued in the past study regarding the duration of each session. The findings of this current study disclosed that time as discussed by the researcher in 2014 has the potential contribution on the effects of the instruction on the students' reading ability. Hence, the extended period of time in instructing metacognitive reading strategies as exercised in this research is able to shed new light on this particular point.

Evidently, both the awareness of reading strategies used among Thai EFL learners and the reading performance obtained from the standardized reading test were improved with statistical significance level. 


\section{Implications for Instruction and Further Research}

The research findings can be an initiative for both EFL reading class and further research related to ELT and EFL. The improvements perceived from both the awareness of reading strategy used could lead EFL teachers to design learning activities that allow students to interact among one another, sharing their past experiences on learning strategies used, to expand the knowledge on strategy application, for this contributes to new approaches of employing learning strategies. In addition, the feedbacks students may share among one another lead them to be critical learners.

Concerning the implications for further research, this research can be a pilot study related to metacognitive reading strategy instruction. The exploration on the improved awareness of reading strategies among students in this study leaves room for researchers to investigate the perceived effects of the instruction SORS could not yield. This can be obtained through the use of qualitative research tools: interviews, observations, think-aloud protocols, for example.

The introduction to the instructional model of metacognitive reading strategies in this research study suggests opportunities to investigate on whether or not the instructional model can be applicable in other EFL contexts. The findings of future research can constitute and build up on the knowledge toward EFL reading phenomena.

\section{Conclusion}

Second language acquisition becomes crucial for effective communications among global citizens, thanks to the expansion of business and industry worldwide. Exploring into the world of knowledge nowadays through reading is considered a vital enterprise for learning in the age of globalization where the information influx demonstrates every aspect of living across the globe. In the realm of FL education, learners encounter while reading a number of factors, including metacognitive knowledge. To equip learners with tools for future explorations in the world today, metacognitive strategies with regards to EFL reading becomes the centrality of this present investigation. With a semester-long metacognitive strategy instruction in EFL reading class, the empirical findings of this study significantly contribute to our understanding toward the effects of such instruction on the students' reading ability.

The instruction activities did not only expose learners to the actual usage of reading strategies, but through discussions in small groups did they also vibrantly share one another their viewpoints toward each strategy's implementation. The exchange improved more or less these learners' awareness on metacognitive reading strategies, for later application in individually assigned and actual reading tasks. With the stress on the effectiveness of strategy use rather than on accurate responses to the questions asked, the students seemed to absorb the knowledge of metacognitive reading strategies. This was as evidenced in the improved reading test scores with statistical significance.

\section{References}

Albazi, S., \& Shukri, N. (2016). Evaluating the effect of metacognitive strategy training on reading comprehension of female students at KAU. International Journal of Applied Linguistics \& English Literature, 5(3), 172-183. https://doi.org/10.7575/aiac.ijalel.v.5n.3p.172

Brown, A. L. (1980). Metacognitive development and reading. In R. J. Spiro, B. Bruce, \& W. F. Brewer (Eds.), Theoretical issues in reading comprehension (pp. 453-479). Hillsdale, NJ: Erlbaum.

Chomphuchart, N. (2007). A cognitive-based study of Thai EFL graduate students' reading strategy use. Journal of English Studies, 3, 50-84.

DeWaelsche, S. A. (2015). Critical thinking, questioning and student engagement in Korean university English courses. Linguistics and Education, 32(Part B), 131-147. https://doi.org/10.1016/j.linged.2015.10.003

Djamàa, S. (2016). Reading the book versus 'reading' the film: Cinematic adaptations of literature as catalyst for EFL students' critical thinking dispositions. Journal of Language Teaching \& Research, 7(2), 252-263. https://doi.org/10.17507/jltr.0702.03

Ellis, R., Loewen, S., Elder, C., Erlam, R., Philp, J., \& Reinders, H. (2009). Implicit and explicit knowledge in second language learning, testing and teaching. Bristol: Multilingual Matters.

Fahim, M., \& Sa'eepour, M. (2011). The impact of teaching critical thinking skills on reading comprehension of Iranian EFL learners. Journal of Language Teaching \& Research, 2(4), 867-874. https://doi.org/ $10.4304 / \mathrm{jltr} .2 .4 .867-874$

Flavell, J. H. (1979). Metacognition and cognitive monitoring: A new area of cognitive-developmental inquiry. 
American Psychologist, 34, 906-911. https://doi.org/10.1037/0003-066X.34.10.906

Gandhimathi, S., \& Ganesan, R. (2010). Pavlovian neutral stimulus with the extempore Responsive-reaction of L2 learners. International Journal of the Humanities, 8(3), 41-45. https://doi.org/10.18848/ $1447-9508 / \mathrm{CGP} / \mathrm{v} 08 \mathrm{i} 03 / 42870$

Grenfell, M., \& Harris, V. (1999). Modern languages and learning strategies: In theory and practice. London: Routledge.

Ismail, N. M., \& Tawalbeh, T. I. (2014). Effectiveness of a metacognitive reading strategies program for improving low achieving EFL readers. International Education Studies, 8(1), 71-87. https://doi.org/ 10.5539/ies.v8n1p71

Iwai, Y. (2016). The effect of explicit instruction on strategic reading in a literacy methods course. International Journal of Teaching \& Learning In Higher Education, 28(1), 110-118.

Jacobs, J., \& Paris, S. (1987). Children's metacognition about reading. Issues in definition, measurement, and instruction. Educational Psychologist, 22, 255-278. https://doi.org/10.1207/s15326985ep2203\&4_4

Jaengsaengthong, W. (2016). Metacognitive reading strategies used by Thai EFL university students. Journal of Graduate Studies in Northern Rajabhat Universities, 6(11), 1-14.

Koda, K. (2005). Insights into second language reading: a cross-linguistic approach. Cambridge: Cambridge University Press.

Lien, H. (2016). Effects of EFL individual learner variables on foreign language reading anxiety and metacognitive reading strategy use. Psychological Reports, 119(1), 124-135. https://doi.org/10.1177/ 0033294116659711

Liu, J. (2010). Language learning strategies and its training model. International Education Studies, 3(3), 100-104. https://doi.org/10.5539/ies.v3n3p100

Liu, S. (2014). L2 reading comprehension: Exclusively L2 competence or different competences?. Journal of Language Teaching and Research, 5(5), 1085-1091. https://doi.org/10.4304/jltr.5.5.1085-1091

Meniado, J. C. (2016). Metacognitive reading strategies, motivation, and reading comprehension performance of Saudi EFL students. English Language Teaching, 9(3), 117-129. https://doi.org/10.5539/elt.v9n3p117

Mokhtari, K., \& Reichard, C. (2002). Assessing students' metacognitive awareness of reading strategies. Journal of Educational Psychology, 94(2), 249-259. https://doi.org/10.1037/0022-0663.94.2.249

Mokhtari, K., \& Sheorey, R. (2002). Measuring ESL students' awareness of reading strategies. Journal of Developmental Education, 25, 2-10.

O’Malley, J. M., \& Chamot, A. U. (1990). Learning strategies in second language acquisition. Cambridge: Cambridge University Press.

O'Malley, J. M., \& Chamot, A. U. (1994). The CALLA handbook: Implementing the cognitive academic language learning approach. N.J.: Addison-Wesley, Reading MA.

Oxford, R. L. (1990). Language learning strategies: What every teacher should know. Boston: Heinle \& Heinle.

Oxford, R. L., \& Burry-Stock, J. (1995). Assessing the use of language learning strategies worldwide with the $\mathrm{ESL} / \mathrm{EFL}$ version of the strategy inventory of language learning (SILL), System, 23, 1-23. https://doi.org/10.1016/0346-251X(94)00047-A

Pammu, A., Amir, Z., \& Maasum, T. M. (2014). Metacognitive reading strategies of less proficient tertiary learners: A case study of EFL learners at a public university in Makassar, Indonesia. Procedia - Social And Behavioral Sciences, 118(International Conference on Knowledge-Innovation-Excellence: Synergy in Language Research and Practice (2013), Organized by School of Language Studies and Linguistics, Faculty of Social Sciences and Humanities, Universiti Kebangsaan Malaysia (National University of Malaysia), 357-364. https://doi.org/10.1016/j.sbspro.2014.02.049

Pei, L. (2014). Does metacognitive strategy instruction indeed improve Chinese EFL learners' reading comprehension performance and metacognitive awareness?. Journal of Language Teaching \& Research, 5(5), 1147-1152. https://doi.org/10.4304/jltr.5.5.1147-1152

Phaiphimai, J., \& Meesri, R. (2015). Differences in metacognitive awareness of reading strategies of the third year undergrad students among English major and non-English major students. An Online Journal of Education, 10(1), 344-357. 
Pinninti, L. R. (2016). Metacognitive awareness of reading strategies: An Indian context. Reading Matrix: An International Online Journal, 16(1), 179-193.

Pookcharoen, S. (2009). Metacognitive online reading strategies among Thai EFL university students. Dissertation. Indiana University Bloomington.

Pressley, M., \& Afflerbach, P. (1995). Verbal protocols of reading: The nature of constructively responsive reading. New Jersy: Lawrence Erlbaum Associates.

Shaaban, K. A. (2014). Assessment of critical thinking skills through reading comprehension. International Journal of Language Studies, 8(2), 117-140.

Sheorey, R., \& Mokhtari, K. (2001). Differences in the metacognitive awareness of reading strategies among native and non-native readers. System, 29(4), 431-449. https://doi.org/10.1016/S0346-251X(01)00039-2

Sudachit, O. (2005). The role of peer collaborative interaction in a small group reading activity on EFL reading comprehension. Journal of Liberal Arts, 5(2), 180-200.

Wichadee, S. (2011). The effects of metacognitive strategy instruction on EFL Thai students' reading comprehension ability. Journal of college teaching and learning, 8(5), 31-40. https://doi.org/10.19030/tlc.v8i5.4255

Yüksel, İ., \& Yüksel, İ. (2012). Metacognitive awareness of academic reading strategies. Procedia - Social And Behavioral Sciences, 31(World Conference on Learning, Teaching \& Administration-2011), 894-898. https://doi.org/10.1016/j.sbspro.2011.12.164

Zhao, X., \& Zhu, L. (2012). Schema theory and college English reading teaching. English Language Teaching, 5(11), 111-117. https://doi.org/10.5539/elt.v5n11p111

Zhou, J., Jiang, Y., \& Yao, Y. (2015). The investigation on critical thinking ability in EFL reading class. English Language Teaching, 8(1), 83-94. https://doi.org/10.5539/elt.v8n1p83

Zhussupova, R., \& Kazbekova, M. (2016). Metacognitive strategies as points in teaching reading comprehension. Procedia - Social And Behavioral Sciences, 228(2nd International Conference on Higher Education Advances, HEAd'16, 21-23 June 2016, Valencia, Spain), 593-600. https://doi.org/10.1016/ j.sbspro.2016.07.091

\section{Copyrights}

Copyright for this article is retained by the author(s), with first publication rights granted to the journal.

This is an open-access article distributed under the terms and conditions of the Creative Commons Attribution license (http://creativecommons.org/licenses/by/4.0/). 